\title{
DESIGNING ZONING OF REMOTE SENSING DRONES FOR URBAN APPLICATIONS: A REVIEW
}

\author{
M.N. Norzailawati ${ }^{\text {a* }}$, A. Alias ${ }^{\text {a }}$, R.S. Akma ${ }^{a}$ \\ An Urban and Regional Planning Department, Kulliyah Architecture and Environmental Design, \\ International Islamic University of Malaysia, 50728 Kuala Lumpur, Malaysia \\ norzailawati@iium.edu.my
}

Commission VI, WG VI/4

KEY WORDS: Drones, Zoning, Remote Sensing, Urban Planning and Regulations.

\begin{abstract}
:
This paper discusses on-going research related to zoning regulation for the remote sensing drone in the urban applications. Timestamped maps are presented here follow a citation-based approach, where significant information is retrieved from the scientific literature. The emergence of drones in domestic air raises lots understandable issues on privacy, security and uncontrolled pervasive surveillance that require a careful and alternative solution. The effective solution is to adopt a privacy and property rights approach that create a drone zoning and clear drone legislatures. In providing a differential trend to other reviews, this paper is not limited to drones zoning and regulations, but also, discuss on trend remote sensing drones specification in designing a drone zones. Remote sensing drone will specific according to their features and performances; size and endurance, maximum airspeed and altitude level and particular references are made to the drones range. The implementation of laws zoning could lie with the urban planners whereby, a zoning for drone could become a new tactic used to specify areas, where drones could be used, will provide remedies for the harm that arise from drones, and act as a different against irresponsible behaviour. Finally, underlines the need for next regulations on guidelines and standards which can be used as a guidance for urban decision makers to control the drones' operating, thus ensuring a quality and sustainability of resilience cities simultaneously encouraging the revolution of technology.
\end{abstract}

\subsection{INTRODUCTION}

The innovation of drones' technologies has challenged a new regulation on guidelines and standards in many development countries. A drone is a system that set of complementary technologies brought together with their own class to fulfil a specific task. The drone can range in size and form and are typically described according to weight, endurance, purpose of use and altitude of the operation. (Jenkins, 2015). According to Department of Civil Aviation (DCA), a small aircraft is defined as any unmanned aircraft weighing not more than $20 \mathrm{~kg}$. The drone has been served the needs of large-scale low-altitude imaging and geospatial information users and developing an industry of its own (Cho, et al., 2013; Mayr, 2013; and Petrie, 2013). The data retrieved by drones can be used quickly to provide up-to-date, area-wide and cost-effective transformation data or images into translatable information through mapping of the urban morphology (Jenkin, 2015).

According to FAA report, in 2010, it was predicted that by the end of the decade there would be as many as 30,000 drones flying in the U.S airspace. However, the emergence of drones in domestic air raises lots understandable issues on privacy, security and uncontrolled pervasive surveillance that require a careful and alternative solution. The effective solution is to adopt a privacy and property rights approach that create a drone zoning and clear drone legislatures. This paper explores an existing researchs on the use of remote sensing drone in creating a drone zoning for urban application. It will focus on drone's evolutions, in the context of urban applications, zoning and planning direction and a preliminary review of current policies and restrictions. In establishing a specific zoning for drones, it is important to examine an issues from multiple points of view. After all, this review also briefly discuss the current state of regulations framework affecting drone operations that will maximize the ratio of a nuisance to the utility in favour of people at large, not particular social group or economic class.

\subsection{EVOLUTION OF DRONE}

A drone can be defined as a system with "an aircraft with the capacity to fly semi or fully autonomously thanks to an onboard computer and sensors" (CielMap, 2012) or an aircraft without the pilot on-board (ICAO, 2011). Meanwhile, Aeronautical Information Services (AIC), DCA defined as an aircraft is designed to operate with no human pilot on board (AIC, 2008). The following definition associated with the various international drones terminologies are shown in Table 2. Commonly, the term of UAV, UAS and RPAS can essentially be used interchangeably to refer to unmanned aircraft and the systems that connect them to their pilots on the ground.(Jenkins,2015). Model aircraft, however, are different from UAVs in the fact it used for recreational or leisure purposes and thus not covered in certain country regulation like Canadian. Using a Google Trends, one sees that Internet usage of the word UAV in 2013 has diminished to almost half of the amount registered in 2005. Yet, this might be partially explained by the new, popular term "drone." (Colomina and Molina, 2014). Drones have a long history dating back to the late $16^{\text {th }}$ century when their precursors known as hot - air 
balloons were developed and later used by Austria to attack Venice in 1849 with a boomerang effect from the fully stocked explosives (Ulrike, 2015). Thereafter, it continuously and rapidly evolves with the advent of new technology during and after military warfare such as the two World Wars, Lebanon war, NATO operations and pacification, anti - terrorism and stabilization of failed states (Tyokumbur, 2015). Table 1 shows the evolution of drones in past a few decades.

\begin{tabular}{|c|c|c|}
\hline Period & Years & Chronology of Drones \\
\hline $\begin{array}{l}\text { Pre-Aviation } \\
\text { UAVs }\end{array}$ & $1700 \mathrm{~s}$ & $\begin{array}{l}\text { Primitive Technology was } \\
\text { used for war and surveillance }\end{array}$ \\
\hline \multirow{11}{*}{$\begin{array}{l}\text { Drone is Used for } \\
\text { Military and } \\
\text { Surveillance } \\
\text { purposed. }\end{array}$} & $1910 \mathrm{~s}$ & $\begin{array}{l}\text { World War 1, U.S military } \\
\text { took a first UAVs flights in } \\
\text { WW1 }\end{array}$ \\
\hline & 1916 & $\begin{array}{l}\text { UAS were born (A.M. Low's } \\
\text { "Aerial Target" of 1916; the } \\
\text { Wright brothers Hewitt-Sperry } \\
\text { Automatic airplane also in } \\
\text { 1916) }\end{array}$ \\
\hline & $1930 \mathrm{~s}$ & $\begin{array}{l}\text { Development of pilotless } \\
\text { aircraft in U.S. }\end{array}$ \\
\hline & $1940 \mathrm{~s}$ & $\begin{array}{l}\text { Early drone in Oregon- A } \\
\text { Japanese balloon bomb kills } \\
\text { six people in rural Eastern } \\
\text { Oregon }\end{array}$ \\
\hline & $1960 \mathrm{~s}$ & $\begin{array}{l}\text { World first robotics company } \\
\text { "Unimation" is founded. }\end{array}$ \\
\hline & $\begin{array}{l}1970 \mathrm{~s} \\
- \\
1980 \mathrm{~s} \\
\end{array}$ & $\begin{array}{l}\text { Potential in Land Use } \\
\text { Mapping }\end{array}$ \\
\hline & $1980 \mathrm{~s}$ & $\begin{array}{l}\text { Israel used airborne drones to } \\
\text { neutralize Syrian air defences. }\end{array}$ \\
\hline & 2000 & $\begin{array}{l}\text { U.S budget mandates that all } \\
\text { attack aircraft be an unmanned } \\
\text { vehicle. }\end{array}$ \\
\hline & 2001 & $\begin{array}{l}\text { First Predator usage }-3000 \\
\text { UAVs and MQ-1 Predator } \\
\text { known a Killer Predator are } \\
\text { used on Afghanistan War. }\end{array}$ \\
\hline & 2002 & $\begin{array}{l}\text { First used an Unmanned Aerial } \\
\text { Vehicle (UAV) by CIA }\end{array}$ \\
\hline & 2010 & $\begin{array}{l}\text { Military has } 12,000 \text { drones in } \\
\text { services }\end{array}$ \\
\hline \multirow{3}{*}{$\begin{array}{l}\text { Developed and } \\
\text { Proposed } \\
\text { "Comprehensive } \\
\text { Plan" and rule- } \\
\text { making for non- } \\
\text { government and } \\
\text { public drones. }\end{array}$} & 2012 & 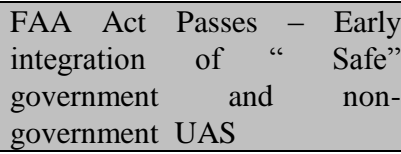 \\
\hline & 2013 & $\begin{array}{l}\text { Visionary technology and } \\
\text { service companies aware the } \\
\text { benefits of drones usage. }\end{array}$ \\
\hline & 2015 & $\begin{array}{l}\text { Drone is on navigating toward } \\
\text { commercial application: } \\
\text { starting with E-Commerce and } \\
\text { retail. }\end{array}$ \\
\hline Future & $\begin{array}{l}2015- \\
\text { future }\end{array}$ & $\begin{array}{l}\text { New definition referring to } \\
\text { drones as Remote Piloted } \\
\text { Aircraft System (RPAS), } \\
\text { which will soon become the } \\
\text { recommended term } \\
\text { internationally as ICAO. } \\
\text { (Council of the European } \\
\text { Union,2012) }\end{array}$ \\
\hline
\end{tabular}

\begin{tabular}{|c|l|}
\hline Term & \multicolumn{1}{|c|}{ Definition } \\
\hline Unmanned Air Vehicle \\
(UAV)
\end{tabular}$\quad \begin{aligned} & \text { UAVS is a "power driven } \\
& \text { aircraft, other than a model } \\
& \text { aircraft, that is designed to fly } \\
& \text { without a human operator on } \\
& \text { board." (Department of Justice, } \\
& \text { 2014) }\end{aligned}$

Table 2: The various Terminologies on Drone (Source: Jenkins, 2015)

\subsection{GEOMATICS MARKETS AND DRONES APPLICATIONS}

Geomatics market is a market assumption based on numerous fact bases, primary and secondary research, and inquiry analysis and extensive network of industry contacts.(Gartner Market Forecast, 2016) The analysis is important to the investor to keep update for their business marketing and profit. In the drone's Geomatics market perspectives, (Gartner, Annual Report 2014 Gartner, 2014) analyse that in the next three or five years, the use of a drone in agriculture industry will be a major driver /enabler for commercial drones. It versatile and diversity has the potential to increase yields and reduce costs which can envision at all sizes levels of commercial agriculture. The recent report by United States Department of Agriculture (USDA) in 2014, crops is planted on 426 million acres in the U.S. Renowned of that, 71 million acres are "treated" by aerial application (crop dusting). The number of acres being treated by aerial applications has the potential to grow.

Table 1: The Evolution of Drones Function 
The recent studies have shown that aerial application is a more effective, and less expensive, method for chemical spraying and/or irrigation than that of tractors. The potential for the drone to take over in aerial applications is increased because drones are not limited to just this one function. Additionally, due to progressively decreasing costs and rapidly rising public demand, drones have become a vanguard growth industry. In U.S markets, they predict the spending on drones will nearly double over the next decade, growing from the current worldwide drone expenditures of $\$ 5.9$ billion to $\$ 11.3$ billion annually. These annuals totals are projected to reach more than $\$ 94$ billion in the next 10 years according to study presented at the Association for Unmanned Vehicle Systems International (Jenkins,2015 and CCUVS,2015a). While, the U.S industries have been estimated 50 companies, universities, and government organizations are developing over 150 different unmanned aircraft designs. (Wood, 2013).

According to ISOFocus online magazine, the number of development centres and manufacturers of UASs is increasing by $3 \%$ to $7 \%$ annually. (Gasiorowski,2015). As a result of the increasing use, accessibility and affordability of drones, there are consequently several impacts that it could have as a result of its widespread applications such as in agriculture sectors, remote sensing fields, on-demand infrastructure, reportage and information and urban disaster and planning. In the context of agriculture sectors, for instance, a HALE UAV, Pathfinder-Plus was used to demonstrate this on a coffee plantation in Hawaii (Herwitz, 2004); others studied in Rangelands (Rango, 2006) and in Japan, these items are considered to be an integral part of farm equipment (being catalogued as "flying ploughs). Meanwhile, a successful experimental program by the Oregon State University (OSU), Hermiston Agricultural Research and Extension Centre (HAREC) program, in the experimenting with UAS integrate with remote sensing technology to improve crop management and yields with the name of sUAS-, are equipped with high-resolution cameras and infrared sensors have flown throughout a farm to detect the beginnings of a pest infestation or dry parts of a crop, reporting the data and enabling the farmer to deploy selective watering and pest management to conserve water and avoid overuse of pesticides.

Rapid response imaging using UAVs has received a lot of attention as well. It has been demonstrated for road accident simulations (Haarbrink, 2006) and in many cases of forest fire monitoring (Restas, 2006 and Casbeer, 2006). UAVs have also been proposed as platforms to monitor volcanoes (Buongiorno, 2005). Beside that the flexibility of UAVs in traffic monitoring ( Puri,2007 and Doherty,2004) offer a real-time aerial video stream, allowing persistent data collection and analysis, but integrating with laser scanner drone would record compressively the scene of traffic congestion or traffic accident which contribute in simplified the drawing up of the accident report. In United Stated, Department of Agriculture (USDA) and NASA have used drone a named "Ikhana" to gather information that helps fight raging forest fires in California, USA( NASA,2010). Drones could also be used to track the illegal coal ash spill in North Carolina, USA. The case study of Raleigh; A team of academic researcher from Wake Forest University found that up to 35 million gallons of coal ash and contaminated wastewater spilled into the Dan River of Carolina in 2014. Furthermore, in another case by the drone journalist (Disbrow,R., et. al, 2014) claim that "lone drone": is an alternative way to replace the journalist on the ground on the dangerous or difficult situation which gave beneficial to the safety of news gathered in the field.
At present, infrastructure struggles to keep up with the rising congestion that comes with high demand. This efficient technology development could help relieves some of that burden and improves the global supply chains. The expected, a drone could become widely used to help transport goods within the next five years (Intelligence, 2015). In addition, a drone could benefit in monitoring and in infrastructure inspection. The ability of the drone to sense in three dimensions and high resolution in low altitude will help in monitoring in the complex and problematic area such power plants, ground pipelines inspections, inspecting on a risky construction site and detecting metal strains. In Aspern, Vienna, civilian drones have been used in monitoring the construction activities. The Aspern, Vienna Urban Lakeside project is a completely new district on a 240hectare site on the north-eastern outskirts of the Austrian capital. The district is expected to set new standards for energy efficiency and environmental balance (Ehrenberg, 2014). Internet shopping giant Amazon is another example involve in drone evolution. Its intention to deliver online purchase by using drones in "large portion" of the US population (Booton, 2014). The services called Amazon Prime, aims to deliver packages to a purchaser within 30 minutes. More advances, the social media networking have been influencing by the drone applications. "Dronestagram" allows users to post their aerial photography related to categories for others to see and share (Fox News,2013).

The used of drones also have been widely applied in the context of disaster and rescue management. The Typhoon Haiyan known as Yolanda in the Philippines, struck the South East coast of the country, Dulag, Tacloban on November 8, 2013.It devastated entire communities, tearing a thousand of homes and destroying livelihoods. Swiss humanitarian organisations one of the non-government organisation collaborate with Drone Adventure team discovered the area by flew 29 drone mapping flights in total with a combined flight time of 11.6 hours to create 2D base maps and 3D terrain models of Tacloban, Dulag and Julita municipalities and plan shelter reconstruction. Approximately, $48.6 \mathrm{sq} \mathrm{km} \mathrm{(18.8} \mathrm{sq} \mathrm{mi)} \mathrm{of} \mathrm{land} \mathrm{were} \mathrm{mapped}$ and acquired 5,139 images. The typical ground solution is $5 \mathrm{~cm}$ to $10 \mathrm{~cm}$ per pixel on the size of the area. Another case study, SteadiDrone QU4D has been used as a virtual surveyor tools over Tirana, Albania to mapping the high population in the urban area. Tirana is a historical area with rapid development without proper documentation of property boundaries and ownership. The ability of SteadiDrone QU4D is to extract the features or structures from Motion and Lidar which gives unprecedented density in point clouds to better represent the shapes, edges and planes accurately for geospatial services (L.L.C., 2015).

In contrast, the drone usage has become an issued throughout the Western Hemisphere, particularly in Mexico and the United States, as drones have found a new investor south of the U.S. border: drug smuggling and drug traffickers. It happened when individuals have already used small drones to try to smuggle marijuana into prisons in South Carolina and Georgia. These attempts were discovered because the drones failed to cross over the fence line and crashed, but there could certainly be other instances when drones were able to fly over a prison fence, were unloaded by prisoners, and then managed to fly back unnoticed.( Alejandro Sanchez, 2015) Since 2010, Drug smuggling across the U.S.-Mexican border via drones has been recorded. A crashed UAV was recovered in Tijuana, Mexico, carrying about six pounds (over three kilograms) of methamphetamine. It seems that drones will continue to be 
utilized for moving small quantities of drugs within Mexican territory or over the U.S. border.( Alejandro Sanchez, 2015)

\subsection{REMOTE SENSING DRONES IN URBAN APPLICATIONS}

The evolution of remote sensing has been challenged the previous technologies. This evolution has seen major improvements over the last few years and expected to expand rapidly for civil, commercial, and scientific uses. Their ability to carry remote sensing tools for greater distances, less expensive and capabilities in acquiring the high-resolution data imagery with lower altitudes are being increasingly recognized. However remote sensing drone in the urban application are still relatively new, and there is still limited in understanding of it a scientific application, how the data acquired and decision making.

A remote sensing drone is differing from a public drone. The key different of remote sensing drone is their resolutions levels and capabilities of different sensors compared to public drone which uses for recreational, leisure, hobbies and photography. Remote sensing tools such as radar, RGB photographic sensors, multispectral, hyper-spectral, and thermal imaging, as well as laser scanning tools such as LiDAR, have been used as a successful and integral environmental monitoring and urban planning resources (Harwin.S., et.al 2015). Remote sensing drone is capable of collecting data and attend to process the data input by using the specific tools and specific processing compare to public drone. In term of usage, currently, remote sensing drone have been applied in a professional field such as urban planning management, precision agricultural, urban disaster and rescue, crime monitoring and surveillance. For example, remote sensing drone has been applied to solve the urban issued such as illegal migration observation.

In United States, 2001, along U.S. Mexico border, approximately 250,000 people try to cross the border illegally each year (Passel.et.al, 2014). The specific image spatial and spectral properties such as bandwidth requirement and flight altitudes are required in the migration inspection. This advanced technology provides almost real-time detection of human movement across the landscape (Kelly and Kelly, 2014). In Canada for instance, Halton police have been purchased a drone to use in their investigations since 2009 in police missions including the search for missing persons, probing collisions and investigation of an armed robbery and homicide (Aeryon Labs Inc., 2015).

The remote sensing drone have an additional in a multispectral band such as infrared to detect the temperature of a nuclear reactor in a case study of Fukushima disaster, 2011 which they used a drone assist RQ-4 Global Hawk to observe the condition of Fukushima after the earthquake. In another case, the thermal infrared radiometers, hyper-spectral radiometers Light Detecting and Ranging (LIDAR) instruments and Synthetic Aperture Radar (SAR) are be carried by drones (Rango and Liliberte,2010) had been used to detect the living beings or crimes case during the night or in darkness condition. Image captured from a drone using this camera and sensors can be stitched together and given a geographical reference much like from a satellite or a manned plane can be (Hardin and Hardin,2010). The latest, many private organisations have been developing the drone industry by developing new and innovative ways to apply into their operation. For instance, oil company use the drone to monitor the pipelined and flare stacks. The Flame Out International has identified a requirement for "on-line" flare stacks survey and flare tip condition inspection to the oil and gas customers sites, they identified drones as being able to deliver. Microdrones, developed by a company out of United State has developed a Microdrone which can perform these inspections with thermal imaging, gas leak detection and air sampling for Petron Chem and Process Industries, improving safety and reducing cost (MiscrodroneUAV, 2015). Another example is remote sensing drone equipped with LiDAR (Light Detection and Raging) scanners can produce accurate demonstrations of structures and built environments with accuracy for details such as height, elevation, three-dimensional aerial video, site analysis and projection of proposed design, while software such as Autodesk's 123D Catch and GIS allows drone imagery to be stitched together to create a photorealistic 3D model. As Kevin Lynch stated in his book The Image of The City, this will help to "form the total scene, so that it's easy for the human observer to identify its part and structure the whole".(Jenkins,2015 and Lynch,1960). It can be concluded that drones' application can be programmed just like an industrial robotic arm, but their greater freedom of movement means they can theoretically be used to build much taller and more complex structures faster than conventional methods (Jenkins, 2015).

Remote sensing drone also gives their contribution in archaeology investigation and research field. Blue J. Occupied, an ancient settlement site in northern New Mexico have been revealed by using drone mounted with a thermal camera to detect the hidden Ancestral Pueblo settlements, Blue J which buried under a meter of desert sand. By sending the thermal camera on four, 11-minute drone flights over Blue $\mathrm{J}$, each at a different time of day. A group of researchers revealed many of the community's buried structures. Thermal images accurately record most of the known buildings at Blue $\mathrm{J}$, including revealed that some of the structures were much larger than archaeologists previously thought (Casana,. et al., 2014).

\subsection{DRONES ZONING AND REGULATIONS}

Due to raising a lot of issues regarding privacy and security from drone usage, international law enforcement and regional levels has attempted to create a drone buffer or drone zoning of the area by using remote sensing technologies. Each country has their own regulation and specification regarding to the drone applications. There are two general aspects of drone regulation have been considered which; i) Physical specification and ii) Airspace aspect. However, the consideration of each aspect depends on each country which some country, for example, U.S, India and Canada need all UAVs system registered to the National Aviation Department somehow, Malaysia, the UAVs system for recreational purposed are not required to register with the National Aviation Department. Table 3 shows the general finding of the study review. The Department of Civil Aviation (DCA) Malaysia, today has been warned that the flying of unauthorised drones or unmanned aerial vehicles (UAV) in the vicinity of airports is strictly prohibited and constitutes as an offence under the Civil Aviation Act 1969 (Bernama,2015).

The issued raise a ruckus when the netizens were share two pictures of aircraft descending to land at the KLIA runway. The photographs of planes landing at KLIA were believed are taken by a drone, simultaneously, it presenting a new threat to national security and aviation safety after decades of steady 
improvement in air travel. In December 2014, a civilian drone came closest "near miss" 20feet with an Airbus A320's engine coming on for landing at Heathrow airport, UK. (Pollock,2014). It made troubling when the drones of that size cannot be detected by the radar. It presently that no international or national policies for drones to be in contact with any aircraft airport tower. At present, most of the drones' applications have a capability relate to the planning and servicing needs such as site inspector drone, in autonomous infrastructure mapping and evaluation robot, drone for power grid monitoring and others. Mitchell Sipus, an urban designer say by creating drone zones in urban planning can be beneficial with the right rules. "It's not really that different than regular automobile traffic. Back in the day, cars were invented, people who could afford them started driving like crazy, getting drunk, driving off the road, driving into trees, causing all sorts of chaos", he tells Popular Science. Sipus' proposal also allows planners to specify where drone use is allowed, restricted or banned. For instance, Sipus concept is using traffic lights colours to specify drone zones such as; green for allowed, yellow for restricted area according to the time of day and day of the week and red for banned zone which the areas are restricted at all times.(Sipus,2014).

In Japan, new zoning regulations on the flights of drones and other unmanned aircraft have been imposed by the government. They are ban flights of drones weighing 200 grams or more in crowded residential areas, at altitudes 150 meters or more above the ground, and near airports. (Otake, T., 2015) The effort to enforce no-fly zones across the city by Tokyo's Metropolitan Police Department is launching a drone squad. According to Japan Today (via Popular Science), the squad will patrol no-fly zones and "will search for the operators and order them to ground the drones." If an operator fails to comply, police will scramble large drones up to 10 feet long armed with cameras and nets to take down the unwanted machines. (Walton, 2015) Additionally, the law limits drones to flights below 500 feet (compared to $400 \mathrm{ft}$ in the US and UK), require all operators to keep their craft at least 30 meters from people, buildings and cars, and bans them from locations where large crowds are present, such as at festivals and exhibitions and bans drones larger than $200 \mathrm{~g}$ from dense residential areas, which includes all of Tokyo. The Japan government moved to regulate drone flights after an incident of a drone carrying a small amount of radioactive material was found on the roof of the prime minister's office in April 2015. (Otake, T.,2015).

\begin{tabular}{|c|c|c|c|c|}
\hline \multicolumn{5}{|c|}{ Consideration Aspect in Drone Regulations } \\
\hline \multicolumn{2}{|r|}{$\begin{array}{c}\text { Physical } \\
\text { Specifications }\end{array}$} & \multicolumn{3}{|c|}{ Airspace Aspect } \\
\hline & Weight & Permission & \multicolumn{2}{|c|}{ Type of Buildings } \\
\hline ii) & $\begin{array}{l}\text { Technical } \\
\text { specification }\end{array}$ & Prohibited & \multicolumn{2}{|c|}{ Permission } \\
\hline & $\begin{array}{l}\text { User Usage } \\
\text { and guideline }\end{array}$ & \multirow[t]{2}{*}{ Restricted } & \multicolumn{2}{|c|}{ Restricted } \\
\hline & $\begin{array}{l}\text { Monitoring } \\
\text { eye view }\end{array}$ & & Permanent & $\begin{array}{c}\text { Tempo } \\
\text { rary }\end{array}$ \\
\hline & $\begin{array}{l}\text { Maximum } \\
\text { Flight Height }\end{array}$ & $\begin{array}{l}\text { Allowable / } \\
\text { Controlled }\end{array}$ & \multicolumn{2}{|c|}{ Allowable / Controlled } \\
\hline vi) & License & & & \\
\hline
\end{tabular}

Table 3: General aspect of drone regulation has been considered from each country

\subsection{Drones Regulation}

At present, drone regulations and legislations have been imposed on 56 countries around the world. (Perlman, 2016). Figure 1 shows the distribution of countries that have been imposed the drone regulations during this research has been conducted. Every of each country have their own aspect in term of physical specification and airspace aspect. (Refer Table 3). In the Malaysian context, Department of Civil Aviation, Malaysia (DCA) requirement stated that drone with weighing not more than $20 \mathrm{~kg}$ are allowed to fly with a maximum height of 400 feet above the surface and a prohibition on a flight for the purposes of aerial work. While, United State requirement by Federal Aviation Administration stated, airspace above 700 feet is federally restricted. Airspace below 30 feet is considered part of individual property rights, meaning that a landlord has a right approximately 30 feet of air above it. Ownership of this airspace is occasionally able to be sold for providing through transfer development rights (Sipus.M, 2014).

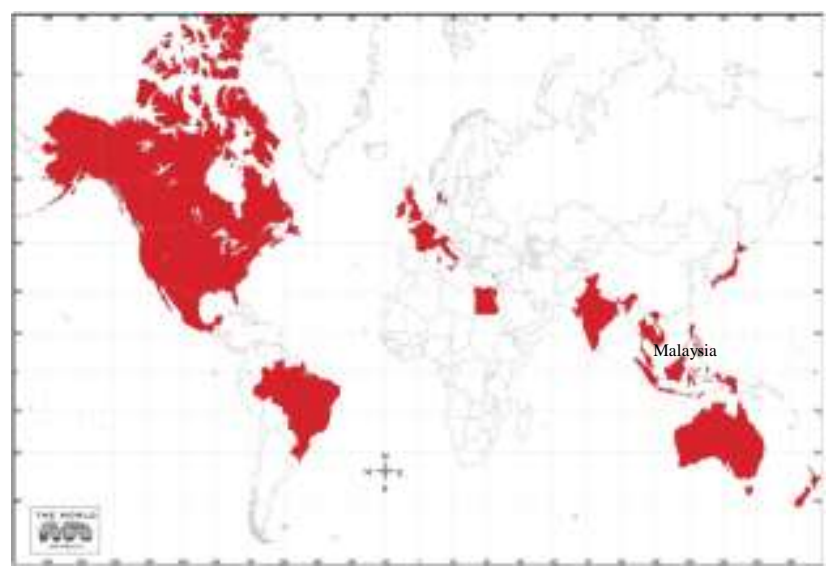

Figure 1. Distribution of the countries that imposed drone regulation until 2016.

Federal Aviation Administration (FAA) has restricted the use of drones for commercial uses but amateurs are free to fly. In June 2014, FAA has been declared that i) any flying drone in a manner that is "in furtherance of a business" is illegal. That includes everything from the obvious (aerial photography ) to the less obvious ii)drone can fly within 5 miles of any airport, helicopter, etc. iii) the drone must operating using "first person view" which cannot use Goggles or any modern "watch it on a monitor" system to fly iv) all existing Federal Aviation Regulations strictly apply to drones. In addition, Article 8 of the Convention on International Civil Aviation (Chicago Convention, 1944) states that "No aircraft capable of being flown without a pilot shall be flown over the territory of a contracting state without special authorization by that state and in accordance with the terms of such an aircraft without a pilot in regions open to civil aircraft shall be so controlled as to obviate danger to civil aircraft". Means that,a person are not allowed to fly their UAVs over the border of another state without permission by the state authority.

In Malaysia, the latest issues had raised when police had arrested the civilian who was flown his drone and fell it on the roof of a prison block during at night. The owner of UAV is arrested under the Act 298, section 10 of the Protected Areas and Protected Places Act 1959. In another case study of the city of Evanston Illinois, the drone uses were banned from flying to the city for use in warrantless surveillance and Carrol County in 
Maryland is looking similar legislation on the use of a drone by law enforcement. There was even recently a temporary event ban during a golf tournament in North Carolina (Sipus.M, 2014).

\subsection{FUTURE OUTLOOK}

The future potential of remote sensing drone, it can serve as an effective tool to collect accurate and current spatial data that improve services and governance by linking spatial data through e-governance, thereby providing governments with new ways to integrate planning, taxation, disaster risk management and the monitoring, mitigation and adaptation to climate change. The key issue faced by most of developing countries is poor data quality and the use of the remote sensing drone has a role to play in faster data quality improvement, flexibility simultaneously help avoid costly mistakes and delays. Also with the capability of low-altitude imaging and high resolution of images, it helps property owners easily identify their zoning or boundaries. In the context of impact on society, economic and nation, the remote sensing drone can encourage the decision makers to organize a better place and secure for human and nation with considering a good mechanism of urban surveillance on achieving resilient and sustainability cities. The drone technology also helps in revitalize neighbourhoods and strengthens the communities within the urban city while reviewing parameter data in a timely fashion. In recommendation, authorities or agencies related can strengthening and improving an existing power conferred under The Civil Aviation Act 1969 on Unmanned Aerial Vehicle (UAV) operation in Malaysia Airspace and extending the powers of local authorities through (National Land Code, 1969 and Act 172) in ensure a better urban planning to achieve sustainable living and resilience development in the cities.

\subsection{CONCLUSION}

As a conclusion, drones have changed the way we view our cities, offering the possibility of witnessing our surrounding and community from above. Their agility and quality imaging abilities make remote sensing drone's advantageous mapping tool for planning development, but there are still several challenges and concerns to be more surmounted. The uncontrolled use of drone embodies threat people and property especially in urban area. Thus, by providing a design drone zoning and specific air regulation and standard, it is important to ensure that drone application and operation is not disruptive to the general activities and safety of the community.

\section{AKNOWLEDGMENT}

The authors greatly acknowledge the International Islamic University of Malaysia for a research grant on Fundamental Research Grant Scheme (FRGS-15-185-0426), Ministry of Higher Education, Malaysia for providing invaluable respective data used in this study. Authors sincerely thank all referees for their suggestions to improve the manuscript.

\section{REFERENCES}

Aeryon Labs Inc. (2015). Aeryon Scout. from; (http://www.aeryon.com/products/avs/aeryon-scout.html/, retrieved 26 Jan 2016)
AIC. (2008 Feb 4). Unmanned Aerial Vehicle (UAV) Operations in Malaysian Airspace. Putrajaya: Aeronautical Information Services.

Bernama. (2015, March 3). Illegal to Fly the Drones Near Airports, DCA Chief Says. Putrajaya, Putrajaya, Malaysia.

Booton, J. (2014). Amazon Rolls Out Sunday Deliveries, Tests Carrier Drones. Retrieved April 3, 2015, from (http://www.foxbusiness.com/technology/2014/04/10/amazonrolls-out-sunday-deliveries-tests-carrier-drones/, retrieved 26 Jan 2016)

Buongiorno, M.F., (2005). Remote Sensing Application to Monitor Active Volcanoes. Use-HAAS Workshop \#1, Brussels, Belgium.

(see http://www.usehaas.org/, retrieved 18 Jan 2016)

Casana, Jesse., John Kantner., Adam Wiewel., and Jackson Cothren. (2014). Archaeological aerial thermography: a case study at the Chaco-era Blue J community, New Mexico. Journal of Archaeological Science , 1-13.

Casbeer, D.W. et al, 2006. Cooperative forest fire surveillance using a team of small unmanned air vehicles. International Journal of Systems Science 37 (6), 351-360.

CCUVS. (2015a). Unmanned Aerial Vehicle Systems Industry Overview from: (http://www.ccuvs.com/industry/, Retrieved 3 Feb 2016)

Cho et al., 2013, G. Cho, A. Hildebrand, J. Claussen, P. Cosyn, S. Morris . Pilotless aerial vehicle systems: size, scale and functions Coordinates, 9 (2013), pp. 8-16

CielMap, (2012). Low-Cost Unmanned Aircraft Systems for Development Projects: A Quiet Revolution. Presentation, Sciences Po Paris.

Cohen, M.J., 2011. Brazilian Eyes in the Sky Focus on the Disappearing Rainforest. Scientific American. http://www.scientificamerican.com/article.cfm?id=brazilianeyes-in-the-sky-focus-on-2011-10

"Drone carrying drugs crashes near US-Mexico border," $B B C$ News, accessed January 23, 2015, From: (http://www.bbc.com/news/world-latin-america-30931367.

Retrieved 15 Jan 2016)

Doherty, P., (2004). Advanced Research with Autonomous Unmanned Aerial Vehicles. In: Proceedings of the 9th International Conference on Principles of Knowledge Representation and Reasoning.

Ehrenberg, N. (2014, October 1). Need Construction Site Surveillance? Hire a Drone! Retrieved january 4, 2016, fromSIEMENS:(http://www.siemens.com/innovation/en/home/ pictures-of-the-future/digitalization-and-software/digitalassistants-construction-site-surveillance.html, retrieved 27 Jan 2016)

Farivar, C. (2016, January 18). Amazon Prime Air: Drones to carry 5lb packages over 10 miles in 30 minutes. Carlifornia, Carlifornia, Carlifornia.

Federal Aviation Administration (FAA). (2014). Busting Myths about the FAA and Unmanned Aircraft. Retrieved from 
(http://www.faa.gov/news/updates/?newsId=76240, $20 \quad$ Dec 2015)

Fox News. (2013). Dronestagram: New social network shows you the world from a drone's perspective. from (http://www.foxnews.com/tech/2013/07/24/dronestagram-newsocial-network-shows-world-from-drones-perspective/, Retrieved January 28, 2016)

Gartner. (2016). Gartner Market Forecast. US. Retrieved 28 January, 2016

Gartner. (2014). Annual Report 2014 Gartner. NewYork: 2014. Retrieved 28 January, 2016

Gasiorowski-Denis, E. (2015, May 5). Drone innovation reaches new heights. Vernier, Geneva, Switzerland.

Haarbrink, RB., Koers, E., (2006). Helicopter UAV for Photogrammetry and Rapid Response. In: The International Archives of Photogrammetry, Remote Sensing and Spatial Information Sciences, Antwerp, Belgium, Vol. XXXVI-1/W44.

Hardin, P.J. and Hardin, T.J., (2010). Small-Scale Remotely Piloted Vehicles In Environmental Research. Geography Compass. 4(9), 1297-1311.

Harwin, S., Lucieer, A., and Osborn, J. (2015). The Impact of Calibration Method on The Accuracy of Points Clouds Derived Using Unmanned Aerial Vehicle Structure-from-Motion(UAVSfM).

Sensing, 7(9),1193311953;doi:10.3390/rs70911933.URL

Herwitz, S.R. et al.,(2004). Imaging From An Unmanned Aerial Vehicle: Agricultural Surveillance And Decision Support. Computers and Electronics In Agriculture 44 (2004) 49-61.

Colomina.I and Molina.P (2014). Unmanned Aerial System for Photogrammetry and Remote Sensing. ISPRS Journal of Photogrammetry and Remote Sensing, 79-97.

ICAO, (2011). ICAO Circular 328, Unmanned Aircraft Systems (UAS). Technical Report. International Civil Aviation Authority. Montral, Canada

Intelligence, S. G. (2015, november 23). The future of commercial drone. from STRATFOR GLOBAL INTELLIGENCE (https://www.stratfor.com/analysis/futurecommercial-drones, Retrieved 25 december 2015)

Jenkins, N. A. (2015). An Application of Aerial Drones in Zoning and Urban Land Use Planning in Canada. Toronto, Ontario, Canada: University of Guelph.

Kelly, A.B.; Kelly, N.M. Validating the Remotely Sensed Geography of Crime: A Review of Emerging Issues. Remote Sens. 2014, 6, 12723-12751.

L.L.C., M. A. (2015, July 28). Personal Mapping Drones In Land Administration, Agriculture And Conservation. Usa, Gainesville, Florida, USA.

L. O.Wallace , A. Lucieer and C. S.Watson. (2012). Assessing The Feasibility Of Uav-Based Lidar For High Resolution Forest Change Detection. International Archives Of The Photogrammetry, Remote Sensing And Spatial Information
Sciences, Volume Xxxix-B7, 2012 Xxii Isprs Congress, 25 August - 01 September 2012, Melbourne, Australia , 1-6.

Lynch, Kevin (1960). The Image of the City. Cambridge MA: MIT Press. OL 5795447M Microdrones.com. "Aerial Video: UAV / Drone Based Film Production".

Mayr. W, (2013). Unmanned aerial systems - for the rest of us 54th Photogrammetric Week, Institut für Photogrammetrie, Universität Stuttgart (2013), pp. 151-163

Microdronesuav. (2015). Microdrones UK | Micro Drone Aerial Photography | Oil \& Gas Inspection UAV / UAS.,From (http://www.microdrones.co.uk/oil-gas-inspection-uav-uas.html, Retrieved 3 Dec 2015)

National Land Code, Act 56 of 1956, Malaysia.

Puri, A. et al., (2007). Statistical Profile Generation for Traffic Monitoring Using Real-time UAV based Video Data. Proceedings of Mediterranean Conference on Control \& Automation 2007, Athens, Greece.

Otake, T. (2015, Dec 9). Japan to ground hobbyist drones in urban areas, impose sweeping restrictions elsewhere. Japan.

Passel, Jeffrey S. and D’Vera Cohn. (2014). “Unauthorized Immigrant Totals Rise in 7 States, Fall in 14: Decline in Those from Mexico Fuels Most State Decreases." Washington, D.C.: Pew Research Center, November.

Perlman, A. (2016, January 12). Drone Laws (by Country). US. Retrieved 2016, from UAV Drone

Petrie.G, 2013. Commercial operation of lightweight UAVs for aerial imaging and mapping. GEO-Informatics, 16 (2013), pp. 28-39

Pollock, T. (2014). Drone was 'within 20ft' of crashing into passenger plane landing at Heathrow. The Telegraph., from (http://www.telegraph.co.uk/news/aviation/11289406/Dronewas-within-20ft-of-crashing-into-passenger-plane-landing-atHeathrow.html., Retrieved 22 December 2015)

Puri, A.et al., 2007. Statistical Profile Generation for Traffic Monitoring Using Real-time UAV based Video Data. Proceedings of Mediterranean Conference on Control \& Automation 2007, Athens, Greece.

Rango, A. and Laliberte, A., (2010). Impact of NASA, 2010. NASA's Ikhana Aircraft Helps Fight 1,000+ California Fires. National Aeronautics and Space Administration. http://www.nasa.gov/offices/ipp/centers/dfrc/news_events/SS-

Ikhana.html flight regulations on effective use of unmanned aircraft systems for natural resources applications. Journal of Applied Remote Sensing. 4(1).

Rango, A. et al.,(2006). Using unmanned vehicles for Rangelands: Current applications and future potentials. Environmental Practise, 8 (3), 159-169.

Ratti, C. (2015, January 22). Drone For Good 'From the US: "Waterfly" - a drone to protect water quality'. from Youtube(https://www.youtube.com/watch?v=jEMSpqQwaRg, Retrieved January 18, 2016) 
Rebecca Disbrow, D. L. (2014). The Corcoran Report. NewYork: PropertyShark.

Réstas, A., (2006). The regulation Unmanned Aerial Vehicle of the Szendro Fire Department supporting fighting against forest fires $1^{\text {st }}$ in the world! Forest Ecology and Management, 234S (2006) S233.

Sipus, M. (2014). Zoning and Urban Land Use Planning for Drones., from (http://www.thehumanitarianspace.com/2014/08/zoning-andurban-land-use-planning-for.html, Retrieved 3 Dec 2015)

The Chicago Convention on International Civil Aviation, December7,(1944). From (http://www.icao.int/publications/pages/doc7300.aspx., Retrieved 3 Dec 2015)

Tyokumbur, E. T. (2015). Review of Potential Ecological Impacts of Peaceful Robotic Drone Use and Policy Implications for Developing Countries. American Journal of Environment Policy and Management, Vol. 1, No. 4, 2015, pp. 67-71.

Ulrike, F. E. (2015). Civilian Drones: Fixing an Image Problem. Source:

http: //isnblog. ethz. ch/security/civilian - drones - fixing - an image - problem (In: Conflict, Politics, Security and Technology). Published on 26 January 2015.

Retrieved 25 Jan 2015.

W. Alejandro Sanchez, "Lift Off: Drone Usage in Latin America Takes Flight," Council on Hemispheric Affairs, accessed January 23, 2015, http://www.coha.org/lift-off-droneusage-in-latin-america-takes-flight/.

Walton, M. (2015, Dec 11). Ars Technica UK. Retrieved Jan 19, 2016, from Tokyo's drone squad will deploy 10-foot drones armed with nets to police the sky: http://arstechnica.com/techpolicy/2015/12/tokyos-drone-squad-will-deploy-10ft-dronesarmed-with-nets-to-police-the-sky/

Wood, L. (2013). Business Wire. From

(http://www.businesswire.com/news/home/20130620005948/en /Research-Markets-Global-Unmanned-Aerial-Vehicle-

Market\#.VR38jvnF-gY, Retrieved 28 January 2015) 